\title{
Left atrial myxoma in a patient with a biventricular pacemaker
}

\author{
Brygida Przywara-Chowaniec ${ }^{1}$, Łukasz Czarnecki ${ }^{1}$, Ewa Nowalny-Kozielska1 ${ }^{1}$, Maciej Gawlikowski², \\ Mariusz Opara ${ }^{1}$, Agata Puzio ${ }^{1}$, Damian Kawecki ${ }^{1}$, Bartosz Wesołowski ${ }^{3}$
}

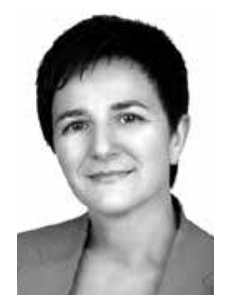

\author{
${ }^{1}$ Second Department of Cardiology in Zabrze, School of Medicine with the Division of Dentistry, Medical University of Silesia \\ in Katowice, Poland \\ ${ }^{2}$ Foundation for Cardiac Surgery Development, Zabrze, Poland \\ ${ }^{3}$ First Department of Cardiology in Zabrze, School of Medicine with the Division of Dentistry, Medical University of Silesia \\ in Katowice, Poland
}

Kardiochirurgia i Torakochirurgia Polska 2016; 13 (4): 383-385

\begin{abstract}
Myxomas make up about 50\% of benign cardiac neoplasms. The most common location is within the left atrium. At the initial stage they do not exhibit any specific clinical symptoms, so they are often diagnosed by accident or during examinations recommended for other reasons. Here we present a case of left atrium myxoma in a patient (a man, age 68 years) with a dual chamber pacemaker. The myxoma did not reveal any clinical symptoms and was discovered in echocardiography during routine diagnostic examination preceding pacemaker implantation. The literature search made by the authors showed that this is the first recorded case of myxoma in a patient after the implantation of a biventricular pacemaker.
\end{abstract}

Key words: myxoma, echocardiography, biventricular pacemaker, Carney's syndrome.

\section{Introduction}

Primary cardiac neoplasms are rare benign tumours, of low incidence (they are found in about $0.03 \%$ of autopsies) [1]. The most common benign cardiac neoplasm (making up $50 \%$ of benign cardiac tumours) is myxoma. In 3/4 cases, myxomas occur in women at the age of 30-60 years. Myxoma early symptoms are non-specific and the disease itself can develop for a long time symptomless.

Later, more serious myxoma symptoms include left ventricular insufficiency (a result of hemodynamic disorders) and thrombotic embolic events originating from the tumour material [2]. Although the initial myxoma diagnostics includes only echocardiography, the detection of the tumour happens most often by chance or during examinations done for other reasons.

The report presents a description of a rare case left atrium myxoma in a man with a biventricular pacemaker (sim-

\section{Streszczenie}

Śluzaki stanowią ok. 50\% łagodnych nowotworów serca. Najczęściej umiejscowione są w obrębie lewego przedsionka. W początkowej fazie nie dają specyficznych objawów klinicznych, dlatego często rozpoznawane są przypadkowo lub podczas badań prowadzonych z innych wskazań. W pracy przedstawiono przypadek śluzaka lewego przedsionka u pacjenta (mężczyzna, wiek 68 lat) z kardiostymulatorem dwujamowym. Śluzak nie dawał żadnych objawów klinicznych i został wykryty w badaniu UKG podczas rutynowej diagnostyki prowadzonej po implantacji stymulatora. Z kwerendy literaturowej wykonanej przez autorów wynika, że jest to pierwszy opisany przypadek śluzaka u pacjenta po wszczepieniu kardiostymulatora dwujamowego.

Słowa kluczowe: śluzak, echokardiografia, kardiostymulator dwujamowy, zespół Carneya.

ulation of DDD type). Probably it is the first reported case of a myxoma in a patient after pacemaker implantation.

\section{Case report}

A man, age 68 years, a retired teacher, was admitted to the Clinical Ward of Specialist Cardiology Hospital in Zabrze in an emergency mode after routine check-up with the general practitioner (GP). Patient's medical history: tachycardia and bradycardia syndrome with losses of consciousness (which was the reason in 2008 for the biventricular pacemaker implantation and stimulation of DDD type), iatrogenic hyperthyroidism (after taking amiodarone due to atrial fibrillation, at the admission in the state of euthyroidism), long-term arterial hypertension, cigarette smoking (20-30 cigarettes per day for 20 years, stopped smoking 20 years ago), denied drinking alcohol. Positive family history. The patient had no clinical symptoms at admission. 


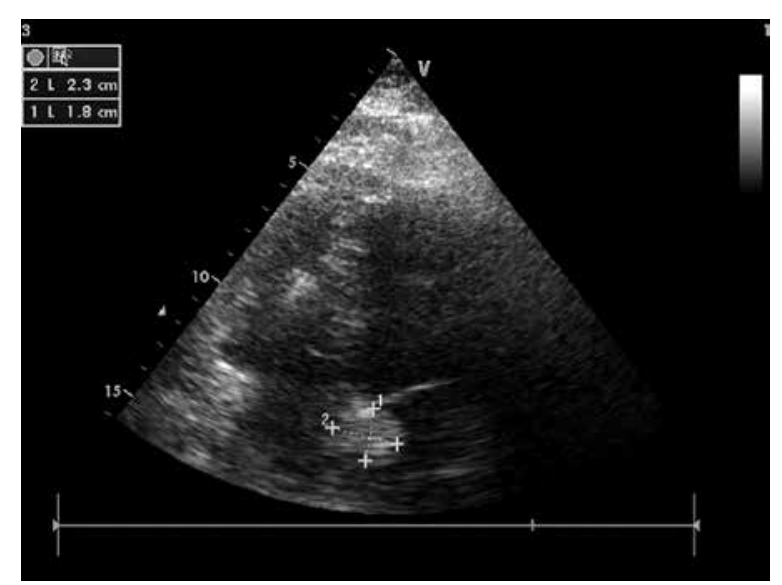

Fig. 1. Tumour of dimensions $2.3 / 1.8 \mathrm{~cm}$, situated in the left atrium (apical four-chamber view)

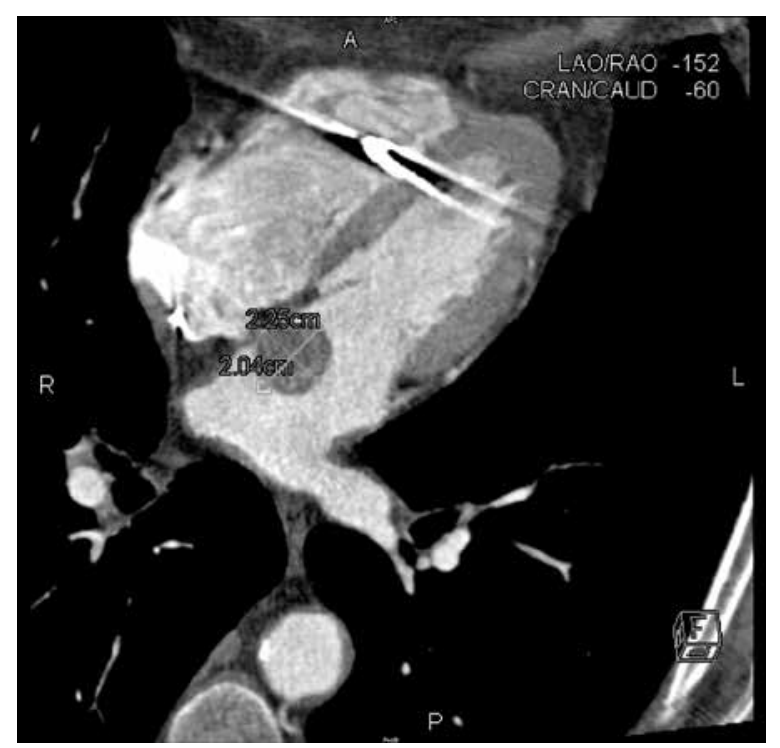

Fig. 2. Image of left atrium myxoma in CT with contrast media (pacemaker electrodes are also visible)

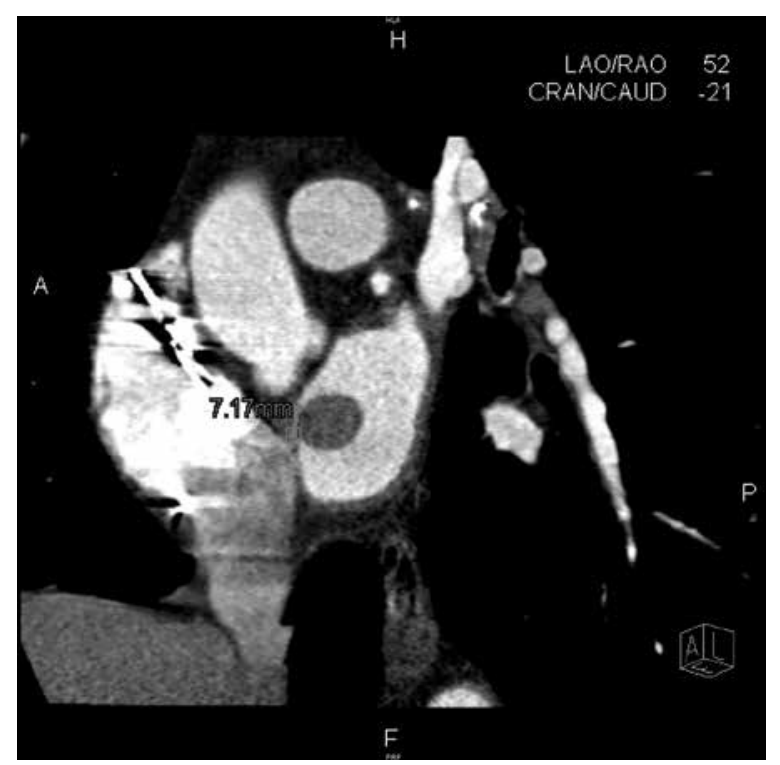

Fig. 3. Myxoma pedunculated to interatrial septum in the vicinity of the foramen oval (pacemaker electrodes are also visible)
A hyperechogenic element 23/18 mm (Fig. 1) adhering tightly to the lower part of the interatrial septum was found in the routine echocardiography. The structure was stuck with the lower pole to the basis of the anterior leaflet of the mitral valve, impairing its mobility. Moreover, the echocardiography showed the pacemaker's electrodes. The size of cardiac chambers was normal.

The ordered computed tomography (CT) examination with contrast media Omnipaque 350 i.v. (volume $90 \mathrm{ml}$, flow $4.5 \mathrm{ml} / \mathrm{s}$, no complications) showed a well-separated tissue mass with smooth surface of dimensions $22.6 \mathrm{~mm}$ $\times 20.4 \mathrm{~mm} \times 16.0 \mathrm{~mm}$ (Fig. 2). The mass was stuck with the $7 \mathrm{~mm}$ wide pedicle to the interatrial septum within the foramen ovale (Fig. 3), at the distance of $1.1 \mathrm{~cm}$ from the mitral ring. Neither balloting nor prolapsing of this structure through the mitral valve was found. The lesion was mostly hypodense in relation to the contrasted blood of density approximately $75 \mathrm{HU}$. An irregular, hyperdense site of dimension up to $6 \mathrm{~mm}$ was visible on its circumference. Moreover, metallic electrodes in the right cardiac chambers were visualized. The lesion was defined as corresponding to the image of myxoma.

Coronarography done before the decision of cardiosurgery showed insignificant hemodynamic parietal lesions in coronary arteries. After cardiosurgery consultations, the patient was qualified for operation in emergency mode. The patient was directed to the Cardiosurgery Clinic in the Silesian Centre of Heart Diseases in Zabrze for surgery. During the surgery, a shapeless mass of mucous consistency and thin content was removed. Histopathology confirmed the myxoma. During the following three check-ups occurring at 6-month intervals no tumour relapse was found.

\section{Discussion}

Cardiac myxoma is a benign, primary heart tumour [1] making up about $50 \%$ of benign heart neoplasms. In 3/4 cases, it occurs in women at the age of 33-60 years. In 10\% of cases, especially in persons below the age of 20 years, myxoma occurs in families, as part of Carney's syndrome, an autosomal dominantly inherited disease [2, 3]. In 93\% of cases, myxomas are located in the atria - left $(75 \%$ of cases) and right (18\% of cases) - but more rarely in ventricles. Multifocal lesions are characteristic of Carney's syndrome [4].

The tumour originates from multipotential mesenchymal cells. Histopathologically, myxomas are built of numerous amorphous structures consisting of groups of joint cells of interstitium type, which are connected with thin-walled blood vessels of capillary morphology. Star cells with processes and fusiform cells emerged in mucosa rich in PASpositive substance are characteristic in microscopic structure. Myxomas can grow out of many sites simultaneously; therefore they can occur in one or many heart chambers. Although the myxoma pattern is of malignant degeneration type, they are treated as being locally malignant [5].

In echocardiography, myxoma is characterized by echogenic heterogeneity which is activated by sites of necrosis, 
haemorrhages and cysts. Myxoma structure is irregular, most often of oval and polyp shape. An echogenic mass found in the imaging should be differentiated from a thrombus, lipomatous hypertrophy of the interatrial septum, breast or bronchial cancer metastases [6]. Transesophageal echocardiography (TEE) is a good supplement in cases where imaging with echocardiography is difficult. It brings much information about the shape and site of lesion attachment and also other changes characteristic for myxoma such as cysts and necrotic sites. Computed tomography is a good method of differentiating myxoma from a thrombus in the left atrium. The parameters significant in the differentiation include: - mobility - myxoma is more often mobile than thrombus, - site of attachment to atrium wall - in the case of myxoma, it is most often a site of foramen ovale,

- prolapse of the lesion into the left heart ventricle - does not occur in cases of thrombi [7].

In the reported patient, the initial myxoma diagnosis was made in the transthoracic echocardiography, while coronarography was done only to enhance the diagnostic procedure preceding surgery.

Clinical myxoma symptoms - if they occur - are nonspecific. Other symptoms such as headache or dizziness, tiredness and effort dyspnoea, sleep apnoea, dyspnoea in horizontal position, nausea, fainting, chest pains, and palpitation can occur. The symptoms of left atrium myxoma often imitate mitral valve stenosis. Less common symptoms include Raynaud's symptom, cough, temperature, loss of weight, and joint pain. In physical examination, a systolic or diastolic murmur can appear; the myxoma sound is present in only about $15 \%$ of patients. Some myxomas cause anaemia, thrombocytopenia, thrombocytosis or inflammatory state. The possible complications include supraventricular arrhythmias, pulmonary oedema, peripheral embolisms, and tumour metastases through blood. Tumour relocation from the atrium into the chamber can be a reason for valve system damage or tendinous chord breaking [8, 9]. None of these features were observed in the above described patient.

Since there is a possibility of the above-mentioned complications, detection of a myxoma should be immediately followed by cardiosurgery where the lesion is removed with the pedicle. After the operation, the patient is monitored regularly in order to detect a possible relapse. It usually occurs most often 4 years after the surgery [10].

In the present case, the myxoma with no clinical symptoms occurred in a man with an implanted biventricular pacemaker. A case like that has not been described in the literature so far. In the described patient, the fact of pacemaker implantation seems not to be related to the myxoma, and the diagnostics and treatment were carried out according to standard procedures.

\section{Disclosure}

Authors report no conflict of interest.

\section{References}

1. Vaideeswar P, Butany JW. Benign cardiac tumors of the pluripotent mesenchyme. Semin Diagn Pathol 2000; 25: 20-28.

2. Parsons AM, Detterdach FC. Multifocal right atrial myxoma and pulmonary ambolism. Ann Thorac Surg 2003; 75: 1323-1324.

3. Coley C, Lee KR, Steiner M, Thompson CH. Complete embolization of a left atrial myxoma resulting in acute lower exetemity ischemia. Tex Heart Inst J 2005; 32: 238-240.

4. Goswami KC, Shrivastava S, Bahl VK, Saxena A, Manchanda SC, Wasir HS. Cardiac myxomas: clinical and echocardiographic profile. Int J Cardiol 1998; 63: 251-259.

5. Read RC, White HJ, Murphy ML, Williams D, Sun CN, Flanagan WH. The malignant potentiality of left atrial myxoma. J Thorac Cardiovasc Surg 1974; 68: 857-868.

6. Sabastine MS, Collucci WS, Schoen FS. Primary tumors of the heart. In: Braunwald E, Zipes DP, Libby P, et al. (eds). The heart disease. Saunders Co., Philadelphia 2004; 1741-1755.

7. Scheffel H, Baumueller S, Stolzmann P, Leschka S, Plass A, Alkadhi H, Schertler T. Atrial myxomas and thrombi: comparison of imaging features on CT. Am J Roentgenol 2009; 192: 639-645.

8. Manus B. Primary tumors of the heart. In: Braunwald's Heart Disease: A Textbook of Cardiovascular Medicine. $9^{\text {th }}$ ed. Bonow RO, Mann DL, Zipes DP, Libby P (eds). Saunders Elsevier, Philadelphia 2012; 1638-1650.

9. McKenna W. Diseases of the myocardium and endocardium. In: Cecil Medicine. $24^{\text {th }}$ ed., Goldman L, Schafer Al (eds). Saunders Elsevier, Philadelphia 2011; 320-339.

10. Kapusta A, Lipiec P, Chrzanowski L, Forys J, Kasprzak JD. Nietypowa przyczyna niewydolności serca - śluzak prawego przedsionka. Pol Arch Med Wewn 2007; 117: 470-472. 